\title{
The Effect of Patent Laws on Economic Growth: Evidence from Cross- Country Panels during 1600-1913 \\ Qiang Chen*
}

School of Economics, Shandong University, 27 Shanda Nanlu, Jinan, Shandong Province PR, China

\begin{abstract}
There has been surprisingly little empirical study about the effect of patent laws per se on economic growth Using a historical panel data of the US and 14 Western European countries during 1600-1913, we estimate a significant positive effect of patent laws on economic growth in different specifications of fixed effects, random effects, time effects, dynamic panel GMM and differences-in-differences models. The results are robust to inclusion of "constraint on executive", exclusion of the UK and US, and using urbanization ratio as a proxy for GDP per capita.
\end{abstract}

Keywords: Patent law; Economic growth; Cross country panel

JEL classifications: O43, E0, K11

\section{Introduction}

Many economists have argued that property-rights institutions are fundamental causes of long-run economic growth [1-3]. However, empirical studies are often plagued by issues of endogeneity and omitted variables bias. In this paper, we focus on the effect of a particular property rights institution - patent laws, on economic growth.

The debate over the effect of patent laws on economic growth is old. This controversy reached such a height during 1850-1875 that the Netherlands repealed its patent law in 1869, which was not reinstated until 1912 [4]. Recently Boldrin and Levine [5] advocates abolishing patent laws.

Although there have been a few empirical studies about the effect of the strength of patent laws (e.g. patent length, breadth and enforcement) on economic growth [6-11], they do not focus on the presence of patent laws per se. These studies typically cover modern time since 1960, long after patent laws were first introduced in Western Europe and the US. Chen [12] uses two panel datasets to study the effect of the presence of patent laws on major invention counts, but not their effect on economic growth. So the empirical question of whether having a patent law can boost economic growth at all are still somewhat open.

Theoretically, patent laws can have both positive and negative effects on economic growth. On the positive side, patent protection can spur innovation by giving inventors' monopolistic rents to cover $R \& D$ expenses and make a profit $[13,14]$. Patent protection may also accelerate the diffusion of new technology as blueprints are publicly available instead of being held as "business secrets" [15]. On the negative side, patent monopoly results in welfare loss to the society, since once invented new technology can be used by anyone with negligible marginal cost. Furthermore, in light of the sequential nature of invention, existing patents may block future inventions [16].

Because of this theoretical ambiguity, empirical studies about effects of patent laws on economic growth become even more important, which is the focus of this paper. Using a panel data of the US and 14 Western European countries during 1600-1913, we estimate a significant positive effect of patent laws on economic growth in different specifications of fixed effects, random effects, time effects, dynamic panel GMM and differences-in-differences models. The results are robust to inclusion of "constraint on executive" (a proxy for property rights protection in general, to be explained later), exclusion of the UK and/or US, and using urbanization ratio as a proxy for GDP per capita.

The rest of this paper is organized as follows. I first discuss econometric methodology, and present main regression results. Then I include "constraint on executive" as an additional control, followed by an alternative differences-in-differences approach as a robustness check. Finally, I use urbanization ratio as a proxy for GDP per capita as another robustness check before conclusion.

\section{Econometric Methodology}

\section{The basic specification}

The basic specification relates a country's average annual growth rate of GDP per capita during a certain period to the initial GDP per capita and initial patent law dummy,

$$
g_{i t}=a+b \ln y_{i, t-1}+g \operatorname{Law}_{i, t-1}+\left(u_{i}+e_{i t}\right),
$$

where $\mathrm{g}$ it is the growth rate for the ith country during period $t$, $\ln y_{i, t-1}$ is the logarithm of GDP per capita in the initial year, and $L a w_{i, t-1}$ is the initial patent law dummy, which equals one if the country has a patent law in the initial year, and zero otherwise. $u_{i}$ is a countryspecific time-invariant disturbance term, while $e_{i t}$ is a country-specific time-variant disturbance term. The parameter $b$ indicates conditional convergence or divergence among countries, conditioning on the presence or absence of patent laws. $g$ is the main parameter of interest, which measures the impact of the initial patent law dummy on the subsequent growth rate.

\section{Data}

We construct a panel of cross-country data for the US and 14 Western European countries during 1600-1913. The reasons why only these countries are included are twofold. First, these countries were

*Corresponding author: Qiang Chen, School of Economics, Shandong University, 27 Shanda Nanlu, Jinan, Shandong Province PR, China, 250100, E-mail: qiang2chen2@126.com.

Received June 23, 2015; Accepted July 16, 2015; Published July 20, 2015

Citation: Chen Q (2015) The Effect of Patent Laws on Economic Growth: Evidence from Cross-Country Panels during 1600-1913 Intel Prop Rights. 3: 145. doi:10.4172/2375-4516.1000145

Copyright: @ 2015 Chen Q. This is an open-access article distributed under the terms of the Creative Commons Attribution License, which permits unrestricted use, distribution, and reproduction in any medium, provided the original author and source are credited. 
relatively homogeneous in their human capital endowment and levels of economic development and institutional setups other than patent laws. Second, including developing countries would only strengthen our results, because during the sample period most developing countries didn't have patent laws, and their growth rates were quite low.

The patent law data are taken from Chen [12] which draws upon Penrose and Khan $[17,18]$ etc. GDP per capita data are from Maddison [19]. The sample period ranges from 1600 to 1913, which covers the years when patent laws were enacted in these sample countries, starting from the UK in 1623 to Finland in 1898. Since all countries in the sample had patent laws after 1913, we do not extend the sample period beyond 1913. We consider four periods, i.e. 1600-1700, 1700-1820, 1820-1870 and 1870-1913, since GDP per capita data are available from Maddison [19] for the year 1600, 1700, 1820, 1870 and 1913. Patent law data and average annual growth rates of GDP per capita are listed in Table 1.

\section{Endogeneity}

A main concern of specification (1) is endogeneity, i.e. the patent law dummy may be endogenous. Obviously, whether and when a country chose to enact a patent law was endogenous. For example, countries that grow faster might choose to establish their patent laws earlier. In that case, causation may run from growth to patent laws, and not vice versa.

However, we have reasons to believe that this endogeneity issue is not severe. Lerner [21,22] finds that political systems and legal traditions played significant roles in shaping national patent laws in his 60-country sample over 150 years, far more important than GDP per capita. Citing historical records, Moser [20] indicates that patent systems were initially adopted in a relative ad hoc manner. For example, the 1623 British patent statute was largely a byproduct of restraining the monarch's arbitrary authority of granting monopolies. America adopted its first patent law in 1790, as mandated by its 1787 constitution. The French revolution gave birth to the first French

\begin{tabular}{|c|c|c|c|}
\hline & Year Patent & $\begin{array}{c}\text { Average Annual } \\
\text { Growth }\end{array}$ & Average Annual Growth \\
\hline \multirow[t]{2}{*}{ Country } & $\begin{array}{c}\text { Law } \\
\text { Established }\end{array}$ & $\begin{array}{c}\text { Rate of GDP per } \\
\text { Capita }\end{array}$ & Rate of GDP per Capita \\
\hline & & $(1700-1820)$ & $(1820-1870)$ \\
\hline Austria & 1810 & 0.0017 & 0.0085 \\
\hline Belgium & 1817 & 0.0012 & 0.0144 \\
\hline Denmark & 1894 & 0.0017 & 0.0091 \\
\hline Finland & 1898 & 0.0017 & 0.0076 \\
\hline France & 1791 & 0.0018 & 0.0085 \\
\hline Germany & 1815 & 0.0014 & 0.0109 \\
\hline Italy & 1859 & 0.0001 & 0.0059 \\
\hline Netherlands & $1817^{1}$ & -0.0012 & 0.0083 \\
\hline Norway & 1834 & 0.0017 & 0.0052 \\
\hline Portugal & 1837 & 0.0010 & 0.0007 \\
\hline Spain & 1820 & 0.0014 & 0.0052 \\
\hline Sweden & 1834 & 0.0017 & 0.0066 \\
\hline Switzerland & 1888 & 0.0017 & 0.0109 \\
\hline UK & 1623 & 0.0026 & 0.0126 \\
\hline US & 1790 & 0.0073 & 0.0134 \\
\hline Average & $1820^{2}$ & 0.0017 & 0.0085 \\
\hline
\end{tabular}

${ }^{1}$ Repealed in 1869 , and reinstated in 1912 .

${ }^{2}$ This is the median. The mean is 1821.8 , which is very close to the median.

Table 1: Patent Laws and Growth Rates for US and 14 W. European Countries. Data Sources: Patent law data [12]. patent law in 1791, and spread the influence of French laws throughout Europe. The Netherlands' unique case - a patent law first established in 1817 , repealed in 1869 and reinstated in 1912 - showcases that the timing of enacting a patent law is more dependent on current political tides than stages of economic development.

Furthermore, the issue of endogeneity is mitigated because only the initial (not concurrent) patent law dummy is included in the regression. The growth rates during the subsequent periods could not change these initial conditions. Last, we also use dynamic panel methods to tackle this potential endogeneity issue.

\section{Omitted variables}

Obviously, many potential factors contributing to economic growth are omitted due to data availability for this historical period, such as human capital and other institutional or policy variables. We believe this is not a serious defect for the following reasons. First, we choose the US and 14 Western European countries in our sample in the hope that they are relatively homogenous in aspects other than the patent laws. Second, timeinvariant omitted variables (e.g. geography or religion) will be dealt with through the fixed effects and differences-in-differences estimators, while time-variant omitted variables will be partially captured through the time effects. Third, as mentioned above, patent laws were adopted in a relatively random manner by countries, and therefore may not be correlated with omitted variables, in which case still producing consistent estimates. Last, omitting variables would increase the standard error of the disturbance term. However, our main parameter of interest, the coefficient for the patent law dummy, is often statistically significant at $1 \%$ level and at least at $5 \%$ level in all specifications.

\section{The quality of patent laws}

Certainly not all patent laws are the same. There were significant differences in the contents and enforcement of patent laws across country and over time, such as patent length, patent application fee and whether prior examination is required. For example, the British patent statue of 1623 was different from the French patent law of 1791, as they belong to different legal families. Lerner $[21,22]$ documented differences of different national patent systems in many dimensions, and their evolution over time. Unfortunately, we can't take into account variations in patent law quality in this panel data setting. Nevertheless, it is reasonable to assume that variations in patent law contents are minor compared with the qualitative difference between the presence of a patent law or its absence. Loosely speaking, while the patent law variable for a country without a patent law is identically 0 , it falls within a narrow interval $\{1-e, 1+e\}$ for a country with a patent law, where $e$ is relatively small. Also, as a partial remedy, these variations in patent law contents would be handled through the fixed effects model.

\section{Main Regression Results}

Table 2 presents main regression results. In all specifications, the patent law dummy is often significant at $1 \%$ level and at least at $5 \%$ level, with a positive sign that is also economically significant. In contrast, the initial GDP per capita is insignificant in all specifications, and even changes sign. It appears that around the Industrial Revolution, besides conditional convergence implied by the neoclassical growth theory, conditional divergence was also at work as leading countries rapidly industrialized while other countries lagged behind. Therefore, the net effect is not statistically significant (Table 2).

\section{Pooled regression}

The benchmark pooled regression estimates a positive coefficient for the patent law dummy that is significant at $1 \%$. It is also economically 
Citation: Chen Q (2015) The Effect of Patent Laws on Economic Growth: Evidence from Cross-Country Panels during $1600-1913$ Intel Prop Rights. 3: 145 . doi: $10.4172 / 2375-4516.1000145$

Page 3 of 7

\begin{tabular}{|c|c|c|c|c|c|c|}
\hline \multicolumn{4}{|c|}{$\begin{array}{c}\text { Dependent Variable: Average Annual } \\
\text { Growth Rate }\end{array}$} & & \multicolumn{2}{|c|}{ \# of observations: 60} \\
\hline $\begin{array}{l}\text { Independent } \\
\text { Variables }\end{array}$ & Pooled & $\begin{array}{l}\text { Fixed } \\
\text { Effects }\end{array}$ & $\begin{array}{c}\text { Fixed and } \\
\text { Time } \\
\text { Effects }\end{array}$ & $\begin{array}{c}\text { Random } \\
\text { Effects }\end{array}$ & $\begin{array}{l}\text { Fixed } \\
\text { Effects } \\
\text { w/o UK } \\
\text { and US }\end{array}$ & $\begin{array}{l}\text { Random } \\
\text { Effects } \\
\text { w/o UK } \\
\text { and US }\end{array}$ \\
\hline Patent Law & $\begin{array}{l}0.0039^{* *} \\
(0.0010)\end{array}$ & $\begin{array}{l}0.0045^{* *} \\
(0.0011)\end{array}$ & $\begin{array}{l}0.0018^{*} \\
(0.0008)\end{array}$ & $\begin{array}{l}0.0040^{* *} \\
(0.0010)\end{array}$ & $\begin{array}{l}0.0043^{* *} \\
(0.0012)\end{array}$ & $\begin{array}{l}0.0034^{* *} \\
(0.0010)\end{array}$ \\
\hline Log (Initial & 0.0008 & 0.0008 & -0.0011 & 0.0008 & 0.0017 & 0.0020 \\
\hline $\begin{array}{l}\text { GDP per } \\
\text { Capita) }\end{array}$ & $(0.0011)$ & $(0.0015)$ & $(0.0014)$ & $(0.0011)$ & $(0.0017)$ & $(0.0012)$ \\
\hline $\begin{array}{l}\text { Period } \\
1820-1870\end{array}$ & & & $\begin{array}{l}0.0062^{* *} \\
(0.0008)\end{array}$ & & & \\
\hline $\begin{array}{l}\text { Period } \\
1870-1913\end{array}$ & & & $\begin{array}{l}0.0034^{* *} \\
(0.0013)\end{array}$ & & & \\
\hline Constant & $\begin{array}{l}-0.0027 \\
(0.0077)\end{array}$ & $\begin{array}{l}-0.0030 \\
(0.0100)\end{array}$ & $\begin{array}{l}0.0089 \\
(0.0095)\end{array}$ & $\begin{array}{l}-0.0027 \\
(0.0078)\end{array}$ & $\begin{array}{l}-0.0093 \\
(0.0120)\end{array}$ & $\begin{array}{l}-0.0109 \\
(0.0086)\end{array}$ \\
\hline $\mathbf{R}^{2}$ & 0.33 & 0.41 & 0.80 & 0.41 & 0.44 & 0.44 \\
\hline
\end{tabular}

Note: Standard errors are in parentheses. Robust standard errors are not used because the sample size is only 60 , and a likelihood ratio test does not reject the null hypothesis of homoskedasticity. *and ${ }^{* *}$ indicate statistical significance at $5 \%$ and $1 \%$ respectively. The sample size for the regression for the last two columns is 52 instead of 60 .

Table 2: The Effect of Patent Laws on Economic Growth, 1600-1913 (Static Panel).

significant with a point estimate of 0.0039 . This suggests that having a patent law may raise the annual growth rate by 0.39 percentage points on average in the subsequent period.

\section{Fixed effects}

In the fixed effects regression, the coefficient for the patent law dummy is again positive and significant at $1 \%$ with a higher point estimate of 0.0045 . A $F$ test with the null hypothesis that all $u_{i}=0$ is not rejected, indicating the pooled regression may be fine.

\section{Random effects}

In the random effects model, the results are very close to the pooled regression. The estimated coefficient for the patent law dummy is 0.0040 and significant at $1 \%$ level. A Hausman specification test doesn't reject the null hypothesis that $u_{i}$ is uncorrelated with regressors, validating the random effects model. However, a Breusch and Pagan LM test doesn't reject the null hypothesis $\operatorname{Var}(u)=0$, which means that the random effects model doesn't gain much efficiency as compared with the pooled regression.

\section{Fixed and time effects}

Using the period during $1600-1700$ as a base, only the last two periods are significant in the regression with both fixed effects and time effects. The positive time effect for the period during 1820-1870 is particularly large with a magnitude of 0.0062 , larger than all other coefficient estimates. The patent law dummy is significant at $5 \%$ and with a reduced magnitude of 0.0018 . Historically, $1820-1913$ was the period when the Industrial Revolution spread from the UK to the rest of Western Europe and the US. It is possible that the rest of Western Europe and the US achieved more growth through borrowing foreign technology rather than original innovations stimulated by the patent laws. A $F$ test rejects the null hypothesis that all $u_{i}=0$ at $1 \%$ level, indicating that the pooled regression would be inappropriate when the time effects are included.

\section{Fixed effects without the UK and/or US}

Since the UK and the US are two countries with the earliest patent law enactment and rapid economic growth, we dropped the UK and the US in the fixed effects regression as a robustness check. The results are virtually the same as the fixed effects model. When only the UK or the US is dropped, the results are similar and not reported.

\section{Random effects without the UK and/or US}

When the UK and the US are dropped in the random effects model, the results are similar to the random effects model. When only the UK or the US is dropped, the results are similar and not reported. As

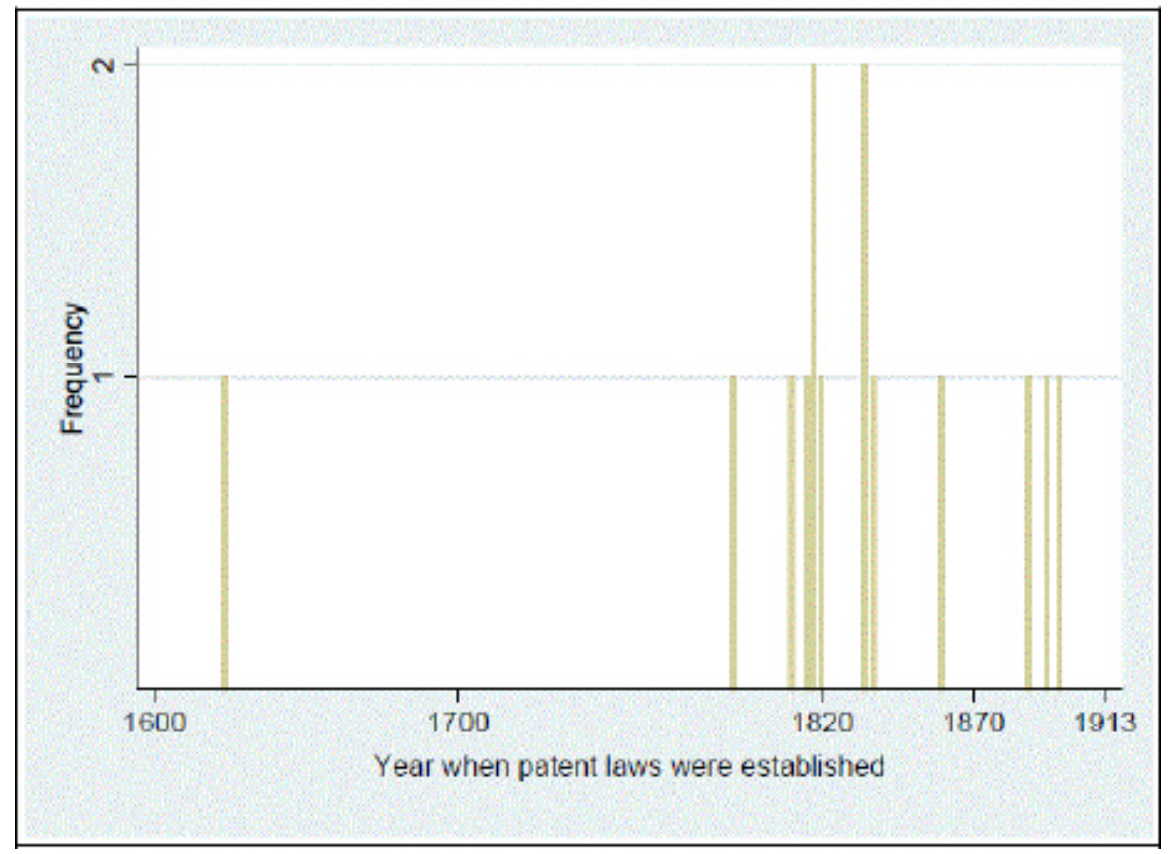

Figure 1: Years when patent laws were established compared with time periods 
another check for outliers in the growth rates, we drop the Netherlands (which had a negative growth rate during 1700-1820) and Belgium (which had the highest growth rate during 1820-1870) in turn, yielding essentially the same results.

\section{When patent laws were established early in a period}

When patent laws were established early in a period but not on the initial year, our methodology may underestimate the effect of patent laws. Fortunately, only four countries fall under this category, i.e. UK, Norway, Portugal and Sweden (Figure 1). When these four countries are dropped in the random effects model, the estimated coefficient for the patent law dummy rises from 0.0040 to 0.0048 , and is still significant at $1 \%$ level (Figure 1 ).

\section{Testing for heteroskedasticity and autocorrelation}

Under a panel data setting, there may be heteroskedasticity across panel units and autocorrelation within each panel unit. We conduct a likelihood ratio test in Stata to test the null hypothesis of homoskedasticity, which is not rejected. We also implement a test of autocorrelation suggested by Wooldridge [23], and the null of no firstorder autocorrelation is easily accepted.

In summary, patent laws have a significant and positive effect on economic growth in different specifications of pooled regression, fixed effects, random effects, and time effects. This effect is also economically significant.

\section{Dynamic panel methods}

Economic growth may have some inertia, i.e. the growth rate of current period may also depend on the growth rate of the previous period. In this case, a dynamic panel setting is appropriate. Furthermore, although we argue that the endogeneity of patent law dummy is not serious, dynamic panel estimation through GMM offers a way to tackle this possible endogeneity formally by explicitly specifying the patent law dummy as an endogenous variable and using its lag and difference as instruments.

Table 3 presents results from dynamic panel estimations. In both difference GMM and system GMM estimations, the coefficient for the patent law dummy is positive and significant at $1 \%$ with a magnitude similar to static panel estimates. The lag of growth rate and initial GDP per capita are both significant at $1 \%$ in difference GMM, but insignificant in system GMM. Sargan statistics for both models indicate that the null hypothesis that all instruments are valid cannot be rejected.

\section{"Constraint on Executive" as an Additional Control}

Patent laws are a measure of intellectual property rights protection, which may be viewed as a culmination of general property rights protection. Therefore, it is possible that what we detect above as the effect of patent laws on economic growth may actually be the effect of property rights protection in general on economic growth. As a robustness check, in this section we include "Constraint on Executive" as an additional control, which is often used in cross-country regressions to proxy for the protection of (physical) property rights, for example Acemoglu et al. [24]. It measures limitations of arbitrary power by the executive, and is presumably correlated with the security of property rights. It is constructed to range between 1 to 7 , where a higher score indicates more constraints, and is coded according to the Polity IV methodology. The "Constraint on Executive" data only go back to 1800 for some countries. As a result, there are only ten countries and two periods (1820-1870 and 1870-1913) left in our sample (Table 4). The regression results are presented in Table 5 . Time effects are insignificant and not reported.

\section{Pooled regression}

In the pooled regression, the estimated coefficient of the patent law dummy is positive but insignificant with a p-value of 0.28 . The coefficient of initial GDP per capita is positive and significant at $1 \%$, indicating conditional divergence on face value. Surprisingly, the coefficient of constraint on executive is positive but insignificant. The weak performance of the patent law dummy and constraint on executive, along with a low $R^{2}$, suggest that the pooled regression may not be suitable.

\section{Fixed effects}

In the fixed effects model, the coefficients for the patent law dummy and constraint on executive are both positive and significant at 5\%. The coefficient for the initial GDP per capita is now negative and but still significant at $1 \%$. A $F$ test with the null hypothesis that all $u_{i}=0$ is strongly rejected at $0.1 \%$, indicating that the pooled regression above is not appropriate. When "constraint on executive" is not included for the sub-sample, the patent law dummy is still significant at $10 \%$ with a p-value of $8 \%$.

\section{Random effects}

In the random effects model, the coefficient for the patent law

\begin{tabular}{|c|c|c|}
\hline \multicolumn{2}{|c|}{ Dependent Variable: Average Annual Growth Rate } \\
\hline $\begin{array}{c}\text { Independent } \\
\text { Variables }\end{array}$ & Difference GMM & System GMM \\
\hline $\begin{array}{c}\text { Lagged Growth } \\
\text { Rate }\end{array}$ & $-2.3590^{* *}$ & -0.6209 \\
\hline Patent Law & $(0.5583)$ & $(0.4976)$ \\
\hline Log (Initial & $0.0038^{* \star}$ & $0.0053^{* \star}$ \\
GDP per Capita) & $(0.0014)$ & $(0.0014)$ \\
\hline Constant & $0.00002^{* *}$ & 0.000003 \\
& $(0.0000)$ & $(0.000006)$ \\
\hline Sample Size & $-0.0124^{\star}$ & 0.0006 \\
\hline Wald $x^{2}$ & $(0.0053)$ & $(0.0036)$ \\
\hline Sargan Statistic & 30 & 45 \\
\hline
\end{tabular}

${ }^{1}$ Because there are too few time periods in the sample, it is impossible to calculate the second order autocorrelation of the first-differenced errors, hence we skip the Arellano-Bond test for zero autocorrelation in first-differenced errors.

* and ** indicate statistical significance at $5 \%$ and $1 \%$ respectively.

Table 3: The Effect of Patent Laws on Economic Growth, 1600-1913 (Dynamic Panel).

\begin{tabular}{|c|c|c|}
\hline Country & Year $\mathbf{1 8 2 0}$ & Year $\mathbf{1 8 7 0}$ \\
\hline Austria & 1 & 3 \\
\hline Denmark & 1 & 3 \\
\hline France & 3 & 7 \\
\hline Germany & 1 & 3 \\
\hline Netherlands & 1 & 6 \\
\hline Portugal & 1 & 3 \\
\hline Spain & 3 & 7 \\
\hline Sweden & 3 & 5 \\
\hline UK & 7 & 7 \\
\hline US & 7 & 7 \\
\hline
\end{tabular}

Note: Data are from Polity IV (http://www.cidcm.umd.edu/polity). There are four instances where it is "-88" in the original Polity IV dataset indicating a war or revolution (i.e. Portugal in 1820; France, Germany and Spain in 1870). Since "-88" doesn't make sense here, we use first normal values from subsequent years instead. 


\begin{tabular}{|c|c|c|c|c|c|}
\hline \multicolumn{4}{|c|}{ Dependent Variable: Average Annual Growth Rate } & \multicolumn{2}{|c|}{ \# of observations: 20} \\
\hline $\begin{array}{l}\text { Independent } \\
\text { Variables }\end{array}$ & Pooled & $\begin{array}{l}\text { Fixed } \\
\text { Effects }\end{array}$ & $\begin{array}{l}\text { Ranc } \\
\text { Effe }\end{array}$ & $\begin{array}{l}\text { Fixed } \\
\text { Effects } \\
\text { w/o UK } \\
\text { and US }\end{array}$ & $\begin{array}{l}\text { Random } \\
\text { Effects } \\
\text { w/o UK and } \\
\text { US }\end{array}$ \\
\hline Patent Law & & & & & \\
\hline $\begin{array}{l}\text { Log (Initial } \\
\text { GDP per } \\
\text { capita) }\end{array}$ & $\begin{array}{l}0.0008^{\star *} \\
(0.0026)\end{array}$ & & & & \\
\hline $\begin{array}{l}\text { Constraint } \\
\text { on } \\
\text { Executive }\end{array}$ & $\begin{array}{c}0.0001 \\
(0.0004)\end{array}$ & & .00 & $\begin{array}{c}0.0002 \\
(0.0001)\end{array}$ & $\begin{array}{l}0.00005 \\
(0.0002)\end{array}$ \\
\hline Consta & $\begin{array}{c}0.0108 \\
(0.0189)\end{array}$ & $\begin{array}{l}0.0752^{* *} \\
(0.0075)\end{array}$ & $\begin{array}{l}0.0656^{* *} \\
(0.0106)\end{array}$ & $\begin{array}{c}0.0560 \\
(0.0078)\end{array}$ & $\begin{array}{l}0.0477^{\star *} \\
(0.0099)\end{array}$ \\
\hline $\mathbf{R}^{2}$ & 0.09 & 0.94 & 0.94 & 0.96 & 0.96 \\
\hline
\end{tabular}

Note: Standard errors are in parentheses. ${ }^{*}$ and ${ }^{* *}$ indicate statistical significance at $5 \%$ and $1 \%$ respectively. The sample size for the last column is 16 instead of 20 .

Table 5: "Constraint on Executive" as an Additional Control, 1820-1913.

dummy is positive and significant at $5 \%$. The coefficient for constraint on executive is positive with a p-value of 0.113. A Hausman specification test rejects the null hypothesis that $u_{i}$ is uncorrelated with regressors, which validates the fixed effects model.

\section{Fixed effects without the UK and/or US}

When the UK and US are dropped in the fixed effects model as a robustness check, the coefficient for the patent law dummy becomes significant at $1 \%$ with a positive sign. When only the UK or the US is dropped, the results are similar and not reported. This means the results are not driven by the UK and the US.

\section{Random effects without the UK and/or US}

When the UK and US are dropped in the random effects model, the coefficient for the patent law dummy also becomes significant at $1 \%$ with a positive sign. When only the UK or the US is dropped, the results are similar and not reported.

In summary, the patent law has a significant, positive and robust effect on economic growth in all specifications when constraint on executive is included as an additional control.

\section{A Differences-in-differences Estimator}

As another robustness check, we use a differences-in-differences estimator for a two-period panel data. The first period is $1700-1820$, and the second period is $1820-1870$. We divide 15 countries in the sample into two groups. The treatment group includes countries having a patent law before 1820, and the control group includes countries without a patent law before 1820 . The year 1820 is chosen because it is the median year of establishing a patent law in the sample (the mean is 1821.8 , which is very close). The Netherlands is included in the treatment group, although it repealed its patent law in 1869.

A differences-in-differences estimator is specified as follows. Suppose the average annual growth rate during 1700-1820 for a particular country is determined by:

$$
g_{1700 \sim 1820}=\mathrm{a}+\mathrm{b}_{1} \ln y_{1700}+\left(u+e_{1}\right),
$$

where $\ln y_{1700}$ is the log of GDP per capita in 1700, and $u$ represents omitted variables that are constant over time, but differs from country to country. The error term $e_{1}$ is assumed to be uncorrelated with $\ln$ $\mathrm{y}_{1700}$. The presence of $\ln \mathrm{y}_{1700}$ in equation (2) indicates possible effect of convergence or divergence. Similarly, suppose the average annual growth rate during 1820-1870 for a particular country is determined by,

$$
\mathrm{g}_{1820 \sim 1870}=\mathrm{a}+\mathrm{b}_{2} \ln \mathrm{y}_{1820}+\mathrm{g} \mathrm{Law}+\left(\mathrm{u}+\mathrm{e}_{2}\right) \text {, }
$$

where $\ln y_{1820}$ is the log of GDP per capita in 1820, and Law is the dummy of having a patent law before 1820 . The error term $e_{2}$ is assumed to be uncorrelated with all regressors in equation (3). We allow the coefficient for $\ln y_{1820}$ in equation (3) to be different from that of $\ln y_{1700}$ in equation (2), as the speed to convergence or divergence may change over time, especially around the Industrial Revolution.

Estimating equations (2) and (3) separately by ordinary least square (which is the difference estimator) can lead to inconsistent estimates, since omitted variables $u$ may be correlated with included regressors. Endogeneity or reverse causality is not a big concern, since regressors ln $y_{1700}, \ln y_{1820}$ and Law happened before the dependent variables.

Subtracting equation (2) from equation (3) yields a differences-indifferences specification,

$$
g_{1820 \sim 1870}-g_{1700 \sim 1820}=-b_{1} \ln y_{1700}+b_{2} \ln y_{1820}+\gamma \text { Law }+\left(e_{2}-e_{1}\right) \cdot
$$

In this way, the new error term $\left(e_{2}-e_{1}\right)$ in equation (4) is uncorrelated with all regressors. Therefore, we can get consistent estimates by ordinary least square. Growth rates $g_{1820 \sim 1870}$ and $g_{1700 \sim 1820}$ are listed in Table 1, while regression results are in Table 6.

The estimated coefficient of the patent law dummy is positive and statistically significant at $5 \%$ with a p-value of $1.9 \%$. Its value is also economically significant. Having a patent law before 1820 can increase average annual growth rate during $1820-1870$ by 0.39 percentage points on average. Also note that the differencesin-differences estimate for the coefficient of patent law dummy is quantitatively very close to estimates from the four-period panel data spanning 1600-1913 in the previous section, which adds robustness to the effect of patent laws. The coefficients for $\ln y_{1700}$ and $\ln y_{1820}$ are not significant. The signs of $b_{1}$ and $b_{2}$ are both negative, indicating there may be a weak convergence.

\section{Using Urbanization as a Proxy for Economic Growth}

Acemoglu et al. [24] argues that long term GDP data from Maddison [19] may be no more than educated guess, and uses urbanization ratio as a proxy for GDP per capita. In this section, we follow this approach as another robustness check. The specification now becomes,

$$
\text { urban_growth }_{i t}=a+\text { burban }_{i, t-1}+g \text { Law }_{i, t-1}+\left(u_{i}+e_{i t}\right),
$$

where urban_growth it is the average annual growth rate of the urbanization ratio for the $\mathrm{i}^{\text {th }}$ country during period $t$, urban $_{i, t-1}$ is the urbanization ratio for the $\mathrm{i}^{\text {th }}$ country in the initial year. One interpretation of equation (5) is that patent laws cause economic growth, which moves together with the urbanization process. The urbanization data for year 1600, 1700, 1750, 1800, and 1850 are taken from Acemoglu et al. [24] (Table 7). The US is excluded for lack of urbanization data, leaving 14 Western European countries in the sample for four periods. The regression results are presented in Table 8. Time effects are insignificant and not reported.

\section{Pooled regression}

In the pooled regression, the estimated coefficient of the patent law dummy is positive and significant at $5 \%$. The coefficient of the initial urbanization is negative and significant at $1 \%$, indicating possible conditional convergence.

\section{Fixed effects}

In the fixed effects model, the estimated coefficient for the patent law 
Citation: Chen Q (2015) The Effect of Patent Laws on Economic Growth: Evidence from Cross-Country Panels during 1600-1913 Intel Prop Rights. 3: 145 . doi: $10.4172 / 2375-4516.1000145$

Page 6 of 7

dummy is positive but insignificant with a p-value of 0.181 . However, a $F$ test with the null hypothesis that all $u_{i}=0$ is easily accepted with a p-value of 0.50 , indicating that the pooled regression is consistent and appropriate.

\section{Random effects}

The random effects model produces almost identical results as the pooled regression. However, a Hausman specification test favors the fixed effects model over the random effects model, which contradicts the $F$ test in the fixed effects models above.

\section{Between estimator}

Although the urbanization ratio may be better measured than GDP per capita, it is an imperfect proxy for GDP per capita. In particular, the relationship between the urbanization ratio and GDP per capita may be nonlinear or noisy. According to Table 6, ten out of the fourteen Western European countries in the sample experienced negative growth of the urbanization ratio in some period during 1600-1850, which is highly unlikely for economic growth data. In fact, according to Maddison [19], the Netherlands was the only country ever experienced negative economic growth during the same period in the sample. The contradiction between the $F$ test and the Hausman specification test above is another sign of noisy data. Therefore, we use the between estimator as a way to smooth out the excessive noise. As a result, the estimated coefficient of the patent law dummy becomes significant at $1 \%$, and the $\mathrm{R}^{2}$ rises from 0.19 to $0.70[25,26]$.

In summary, the patent law dummy has a significant positive effect when the urbanization ratio is used as a proxy for GDP per capita as a

\begin{tabular}{|c|c|c|c|c|}
\hline \multicolumn{5}{|c|}{$\begin{array}{l}\text { Dependent Variable: Difference of average growth rates during } 1820-1870 \\
\text { and } 1700-1820\end{array}$} \\
\hline $\begin{array}{l}\text { Independent } \\
\text { Variable }\end{array}$ & Coefficient & p-value & \# of observations & $\mathbf{R}^{2}$ \\
\hline $\begin{array}{l}\text { Having a patent } \\
\text { law by } 1820\end{array}$ & $\begin{array}{l}0.0039^{*} \\
(0.0014)\end{array}$ & 0.019 & & \\
\hline $\begin{array}{c}\log (\text { GDP per } \\
\text { capita) } \\
\text { in } 1700\end{array}$ & $\begin{array}{c}0.0031 \\
(0.0034)\end{array}$ & 0.385 & & \\
\hline \multirow[t]{2}{*}{$\begin{array}{c}\log \text { (GDP per } \\
\text { capita) } \\
\text { in } 1820\end{array}$} & $\begin{array}{l}-0.0023 \\
(0.0034)\end{array}$ & 0.506 & & \\
\hline & & & 15 & 0.90 \\
\hline
\end{tabular}

Note: Standard errors are in parentheses. ${ }^{*}$ indicates statistical significance at $5 \%$. Table 6: A Differences-in-differences Estimator.

\begin{tabular}{|c|c|c|c|c|}
\hline Country & $\mathbf{1 6 0 0 - 1 7 0 0}$ & $\mathbf{1 7 0 0 - 1 7 5 0}$ & $\mathbf{1 7 5 0 - 1 8 0 0}$ & $\mathbf{1 8 0 0 - 1 8 5 0}$ \\
\hline Austria & 0.0049 & 0.0057 & 0.0051 & 0.0043 \\
\hline Belgium & 0.0027 & -0.0051 & -0.0002 & 0.0021 \\
\hline Denmark & 0.0002 & 0.0022 & 0.0024 & -0.0015 \\
\hline Finland & 0.0011 & -0.0069 & 0.0071 & 0.0044 \\
\hline France & 0.0034 & 0.0019 & 0.0029 & 0.0036 \\
\hline Germany & -0.0017 & 0.0057 & 0.0049 & 0.0018 \\
\hline Italy & -0.001 & -0.0005 & 0.004 & -0.0018 \\
\hline Netherlands & 0.0029 & -0.0037 & 0.0045 & -0.0023 \\
\hline Norway & 0.0048 & 0.0079 & 0.001 & 0.0018 \\
\hline Portugal & 0.0027 & 0.0097 & -0.001 & -0.0032 \\
\hline Spain & -0.0022 & 0.0003 & 0.0069 & 0.0012 \\
\hline Sweden & 0.0051 & 0.0003 & -0.001 & 0.0009 \\
\hline Switzerland & 0.0022 & 0.0046 & -0.0006 & 0.01 \\
\hline UK & 0.0055 & 0.0018 & 0.0086 & 0.0061 \\
\hline
\end{tabular}

Data Source: Calculated [24].

Table 7: Average Annual Growth Rate of the Urbanization Ratio.

\begin{tabular}{|c|c|c|c|c|}
\hline \multicolumn{4}{|c|}{ Dependent Variable: Annual Growth Rate of Urbanization } & \multirow{2}{*}{$\begin{array}{c}\text { \# of } \\
\text { observations: } \\
56 \\
\text { Between } \\
\text { Estimator }\end{array}$} \\
\hline $\begin{array}{l}\text { Independent } \\
\text { Variables }\end{array}$ & Pooled & Fixed Effects & $\begin{array}{l}\text { Random } \\
\text { Effects }\end{array}$ & \\
\hline Patent Law & $\begin{array}{l}0.0035^{*} \\
(0.0016)\end{array}$ & $\begin{array}{c}0.0034 \\
(0.0024)\end{array}$ & $\begin{array}{l}0.0035^{\star} \\
(0.0016)\end{array}$ & $\begin{array}{l}0.0059^{* *} \\
(0.0014)\end{array}$ \\
\hline $\begin{array}{c}\text { Urbanization } \\
\text { (Initial year) }\end{array}$ & $\begin{array}{l}-0.0143^{* *} \\
(0.0049)\end{array}$ & $\begin{array}{c}-0.0489^{* *} \\
(0.0162)\end{array}$ & $\begin{array}{l}-0.0143^{* *} \\
(0.0049)\end{array}$ & $\begin{array}{l}-0.0101^{*} \\
(0.0034)\end{array}$ \\
\hline Constant & $\begin{array}{l}0.0040^{* *} \\
(0.0008)\end{array}$ & $\begin{array}{l}0.0089^{* *} \\
(0.0022)\end{array}$ & $\begin{array}{l}0.0040^{* *} \\
(0.0008)\end{array}$ & $\begin{array}{l}0.0032^{* *} \\
(0.0006)\end{array}$ \\
\hline $\mathbf{R}^{2}$ & 0.19 & 0.19 & 0.19 & 0.70 \\
\hline
\end{tabular}

Note: Standard errors are in parentheses * and ** indicate statistical significance at $5 \%$ and $1 \%$ respectively.

Table 8: Urbanization as a Proxy for GDP per capita, 1600-1850.

robustness check.

\section{Conclusion}

This paper uses a historical panel data for the US and 14 Western European countries during 1600-1913 to empirically test the effect of patent laws on economic growth. The issues of endogeneity and omitted variables bias are taken into consideration. We estimate a significant positive effect of patent laws on economic growth in different specifications of fixed effects, random effects, time effects, dynamic panel GMM and differences-in-differences models. This effect is also economically significant. The results are robust to inclusion of "constraint on executive" as a proxy for general property rights protection, exclusion of the UK and US, and using urbanization as a proxy for GDP per capita. However, since human capital is often deemed an important determinant of economic growth [27], a potential shortcoming of this paper is the lack of human capital data for the sample period, which is a direction for future work.

\section{References}

1. North D, Thomas R (1973) The rise of the western world: A new economic history. Cambridge University Press, Cambridge, UK

2. North D (1981) Structure and change in economic history. WW Norton and Co., New York.

3. Rosenberg N, Birdzell $L$ (1986) How the west grew rich: The economic transformation of the industrial world. Basic Books, New York.

4. Machlup F, Penrose E (1950) The patent controversy in the nineteenth century. Journal of Economic History 10: 1-29.

5. Boldrin M, Levine D (2002) The case against intellectual property. American Economic Review Papers and Proceedings 92: 209-212.

6. Gould D, Gruben W (1996) The role of intellectual property rights in economic growth. Journal of Development Economics 48: 323-350.

7. Thompson M, Rushing F (1999) An empirical analysis of the impact of patent protection on economic growth: An Extension. Journal of Economic Development 24: 67-76

8. Thompson M, Rushing F (1996) An empirical analysis of the impact of patent protection on economic growth. Journal of Economic Development 21: $61-79$

9. Park W, Ginarte C (1997) Intellectual property rights and economic growth Contemporary Economic Issues 15: 51-61.

10. Falvey R, Foster N, Greenaway D (2006) Intellectual property rights and economic growth. Review of Development Economics 10: 700-719.

11. Hu A, Png I(2012) Patent Rights and Economic Growth: Evidence from Cross-Country Panels of Manufacturing Industries. Oxford Economic Papers, 65: 675-698.

12. Chen Q (2008) The Effect of Patent Laws on Invention Rates: Evidence from Cross-Country Panels. Journal of Comparative Economics 36: 694-704. 
Citation: Chen Q (2015) The Effect of Patent Laws on Economic Growth: Evidence from Cross-Country Panels during $1600-1913$ Intel Prop Rights. 3: 145 . doi:10.4172/2375-4516.1000145

Page 7 of 7

13. Nordhaus W (1969) Invention, growth and welfare: A Theoretical Treatment of Technological Change. MIT, Cambridge, MA.

14. Romer $P$ (1990) Endogenous technological change. Journal of Political Economy 98: S71-S102.

15. Moser $P$ (2010) Do patents diffuse localized knowledge spillovers? Evidence from the Geography of Innovations at Four World's Fairs: 1851-1915.

16. Bessen J, Maskin E (2009) Sequential innovation, patents and imitation. Rand Journal of Economics 40: 611-35.

17. Penrose E (1951) The Economics of the International Patent System. Johns Hopkins, Baltimore, MD.

18. Khan B (2005) The Democratization of Invention: Patents and Copyrights in American Economic Development. Cambridge University Press, Cambridge, UK: $1790-1920$.

19. Maddison A (2001) The world economy: A millennial perspective. Organization for economic co-operation and development, Paris, France.

20. Moser P (2005) How Do Patent Laws Influence Innovation? Evidence from Nineteenth Century World's Fairs. American Economic Review 95: 1215-1236.
21. Lerner J (2002) Patent protection and innovation over 150 Years. National Bureau of Economic Research Working Paper No 8977: 1-39.

22. Lerner J (2002) 150 Years of patent protection. American Economic Review Papers and Proceedings 92: 221-225.

23. Wooldridge $\mathrm{J}$ (2002) Econometric analysis of cross section and panel data. MIT Press, Cambridge, MA.

24. Acemoglu D, Johnson S, Robinson J (2005) The rise of Europe: Atlantic trade, institutional change and economic growth. American Economic Review 95: 546-579.

25. Drukker D (2003) Testing for Serial correlation in linear panel-data models Stata Journal 3: 168-177.

26. Marshall M, Jaggers K (2000) Polity IV Project. Political regime characteristics and transitions. Dataset User's Manual. Center for International Development and Conflict Management, University of Maryland, College Park: 1800-1999.

27. Barro R (1991) Economic growth in a cross section of countries. Quarterly Journal of Economics 106: 407-443. 